\title{
The novel IkB kinase $\beta$ inhibitor IMD-0560 prevents bone invasion by oral squamous cell carcinoma
}

\author{
Yukiyo Tada ${ }^{1,2}$, Shoichiro Kokabu ${ }^{1}$, Goro Sugiyama ${ }^{1}$, Chihiro Nakatomi', Kazuhiro \\ Aoki $^{3}$, Hidefumi Fukushima ${ }^{4}$, Kenji Osawa5 ${ }^{5}$ Yasutaka Sugamori ${ }^{3}$, Keiichi Ohya ${ }^{3}$, \\ Masato Okamoto6, Tomoyuki Fujikawa7, Akiko Itai7, Kou Matsuo ${ }^{8}$, Seiji Watanabe ${ }^{2}$ \\ and Eijiro Jimi ${ }^{1,9}$ \\ ${ }^{1}$ Division of Molecular Signaling and Biochemistry, Department of Health Promotion, Kyushu Dental University, Manazuru, \\ Kokurakita-ku, Kitakyushu, Fukuoka, Japan \\ 2 Division of Dental Anesthesiology, Department of Control of Physical Functions, Kyushu Dental University, Manazuru, \\ Kokurakita-ku, Kitakyushu, Fukuoka, Japan \\ ${ }^{3}$ Section of Pharmacology, Department of Bio-Matrix, Graduate School, Tokyo Medical and Dental University, Yushima, \\ Bunkyo-ku, Tokyo, Japan \\ ${ }^{4}$ Department of Physiological Sciences and Molecular Biology, Fukuoka Dental College, Fukuoka, Tamura, Sawara-ku, \\ Fukuoka, Japan \\ ${ }^{5}$ Division of Pathophysiology, Research Center for Genomic Medicine, Saitama Medical University, Yamane, Hidaka-shi, \\ Saitama, Japan \\ ${ }^{6}$ Department of Advanced Immunotherapeutics, Kitasato University School of Pharmacy, Shirokane, Minato-ku, Tokyo , \\ Japan \\ ${ }^{7}$ Institute of Medicinal Molecular Design Inc (IMMD Inc), Hongo, Bunkyo-ku, Tokyo, Japan \\ 8 Division of Oral Pathology, Department of Health Promotion, Kyushu Dental University, Manazuru, Kokurakita-ku, \\ Kitakyushu, Fukuoka, Japan \\ ${ }^{9}$ Center for Oral Biological Research, Kyushu Dental University, Manazuru, Kokurakita-ku, Kitakyushu, Fukuoka, Japan \\ Correspondence to: Eijiro Jimi, email: ejimi@kyu-dent.ac.jp
}

Keywords: NF-KB, IMD-0560, bone invasion, oral squamous cell carcinoma

Received: September 16,2014 Accepted: October 28, $2014 \quad$ Published: October 28, 2014

This is an open-access article distributed under the terms of the Creative Commons Attribution License, which permits unrestricted use, distribution, and reproduction in any medium, provided the original author and source are credited.

\section{ABSTRACT}

Oral squamous cell carcinoma (OSCC) cells display significantly augmented nuclear factor-kB (NF-kB) activity, and inhibiting this activity suppresses malignant tumor characteristics. Thus, we evaluated the effect of IMD-0560, a novel inhibitor of IKB kinase (IKK) $\beta$ that is under assessment in a clinical trial of rheumatoid arthritis, on bone invasion by the mouse OSCC cell line SCCVII. We examined the inhibitory effects of IMD-0560 on NF-KB activity and tumor invasion using human OSCC cell lines and SCCVII cells in vitro. Using a mouse model of jaw bone invasion by SCCVII cells, we assessed the inhibitory effect of IMD- 0560 on jaw bone invasion, tumor growth, and matrix degradation in vivo. IMD-0560 suppressed the nuclear translocation of NF-KB and the degradation of IKBa in OSCC cells. IMD-0560 also inhibited invasion by suppressing matrix metalloproteinase-9 (MMP-9) production in OSCC cells. IMD0560 protected against zygoma and mandible destruction by SCCVII cells, reduced the number of osteoclasts by inhibiting receptor activator of NF-KB ligand (RANKL) expression in osteoblastic cells and SCCVII cells, increased SCCVII cell death and suppressed cell proliferation and MMP-9 production in SCCVII cells. Based on these results, IMD-0560 may represent a new therapeutic agent for bone invasion by OSCC cells. 


\section{INTRODUCTION}

Oral squamous cell carcinoma (OSCC) is the most common malignant tumor of the oral cavity, head and neck [1-3]. The annual incidence of OSCC is estimated to be 400,000 to 500,000 new cases worldwide, which is predicted to increase in the next few decades. Curable lesions that are detected early are rarely symptomatic; thus, preventing fatal disease requires early detection by screening. Treatment consists of surgery, radiation, or both, although surgery plays a larger role in the treatment of most oral cavity cancer. The overall 5-year survival rate is $>50 \%$. However, the poor prognosis for OSCC reflects a limited understanding of the mechanisms underlying local and regional invasion and metastasis that occur in a significant portion of patients, as well as the unsatisfactory responsiveness to conventional systemic therapy in recurrent and advanced disease.

Gingival squamous cell carcinomas frequently invade mandible bone, which is associated with worse prognosis and should be treated surgically by resection. The prevalence of mandibular bone involvement ranges from 12 to $56 \%$ [4-6]. The treatment results of these lesions are typically poor, with nearly $70 \%$ of cases recurring at the primary lesion site, ultimately causing death $[7,8]$. Although controversial, the bone destruction that occurs due to OSCC invasion is thought to be mediated by osteoclasts rather than the carcinoma itself [9]. Recent studies have established that bone resorption by osteoclasts is an important step in the process of bone invasion and metastasis in several types of malignancy, indicating that a complete understanding of the regulation of osteoclastogenesis by OSCC cells is necessary to prevent bone invasion by OSCC cells $[9,10]$.

Nuclear factor- $\kappa \mathrm{B}(\mathrm{NF}-\kappa \mathrm{B})$ represents a family of dimeric transcription factors that are contain a characteristic Rel homology domain. Latent NF- $\mathrm{KB}$, which forms a complex with $\mathrm{I} \kappa \mathrm{B}$, resides in the cytoplasm. This pathway can be rapidly and transiently activated by a wide variety of substances, such as mitogens, cytokines, and microbial components. NF- $\kappa \mathrm{B}$ activation is dependent on a specific I $\kappa \mathrm{B}$ kinase (IKK) complex composed of two catalytic subunits, IKK $\alpha$ (IKK1) and IKK $\beta$ (IKK2), and the regulatory subunit NF- $\mathrm{KB}$ essential modulator (NEMO/IKK $\gamma$ ). Upon activation, IKK phosphorylates specific serine residues in I $\mathrm{I} B$ proteins, triggering their ubiquitination and degradation by the proteasome, thus allowing the NF- $\mathrm{KB}$ dimers to translocate to the nucleus to regulate gene expression [11,12]. Gene-targeting experiments revealed that many pro-inflammatory stimuli require the IKK $\beta$ subunit for NF- $\mathrm{kB}$ activation. The NF$\kappa \mathrm{B}$ activation pathway contributes to the induction of inflammatory mediators, cytokines, chemokines, proteases and inhibitors of apoptosis, and it has been proposed that the NF- $\mathrm{kB}$ pathway might link inflammation to tumor promotion and progression $[11,12]$.
The NF- $\kappa \mathrm{B}$ signaling pathway is activated in many cancers, including OSCC, contributing to the acquisition of malignant characteristics, such as increased invasion, survival, chemoresistance, and angiogenesis of OSCC [1315]. A previous report showed that elevated expression of $\mathrm{NF}-\mathrm{\kappa B}$ correlates to enhanced invasion and metastasis of OSCC [15]. Furthermore, the osteoclast differentiation factor receptor activator of NF- $\mathrm{KB}$ ligand (RANKL) activates NF- $\mathrm{KB}$ in osteoclast precursors to cause differentiation into osteoclasts, and selective inhibitors of NF- $\mathrm{kB}$ inhibit RANKL-induced osteoclastogenesis in vitro and in vivo [16-18].

Recently, novel synthesized chemical compounds that act as IKK inhibitors have been developed [19, 20]. We previously reported that a selective inhibitor of NF- $\mathrm{KB}$, NBD peptide, which disrupts the association of NEMO with both IKKs, prevents bone invasion in an in vivo OSCC model [21]. However, it is very difficult to use this laboratory reagent for clinical application.

IMD-0560, or N-[2,5-bis(trifluoromethyl)phenyl]5-bromo-2-hydroxybenzamide, was developed as novel inhibitor of IKK [22-24]. The molecular structure of IMD0560 was designed by analyzing a binding mode of aspirin to $\operatorname{IKK} \beta[19,20]$. This drug is a selective $\operatorname{IKK} \beta$ inhibitor,

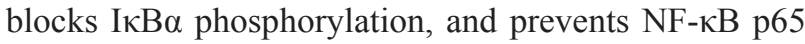
nuclear translocation, and its prodrug is under assessment in a clinical trial for inflammation-related cardiovascular diseases and rheumatoid arthritis [19, 20]. In this study, we examined the potential for the clinical evaluation of IMD0560 for the treatment of bone invasion by OSCC cells.

\section{RESULTS}

\section{IMD-0560 inhibits TNF $\alpha$-induced p65 phosphorylation and IKB $\alpha$ degradation in human and mouse OSCC cells}

Pretreatment with IMD-0560 inhibited TNF $\alpha$ induced p65 phosphorylation (Ser-536) and І ІкB $\alpha$ degradation in a dose-dependent manner in SCCVII, HSC2 , and $\mathrm{Ca}_{9-22}$ cells (Figure 1A). We used IMD-0560 at 1 $\mu \mathrm{M}$ for SCCVII and $10 \mu \mathrm{M}$ for HSC-2 and $\mathrm{Ca}_{9-22}$ cells following experiments, respectively. TNF $\alpha$ induced the translocation of $\mathrm{p} 65$ from the cytoplasm to the nucleus, and IMD-0560 significantly blocked this translocation in HSC-2, $\mathrm{Ca}_{9-22}$, and SCCVII cells (Figure 1B). Pretreatment with IMD-0560 inhibited both I $\mathrm{KB} \alpha$ degradation and p65 phosphorylation induced by TNF $\alpha$ (Figure 1C). IMD-0560 also suppressed $\mathrm{TNF} \alpha$-induced transcriptional activity (Figure 1D). These results strongly indicate that IND-0560 inhibits TNF $\alpha$-induced NF- $\mathrm{KB}$ activation in OSCC cells. 

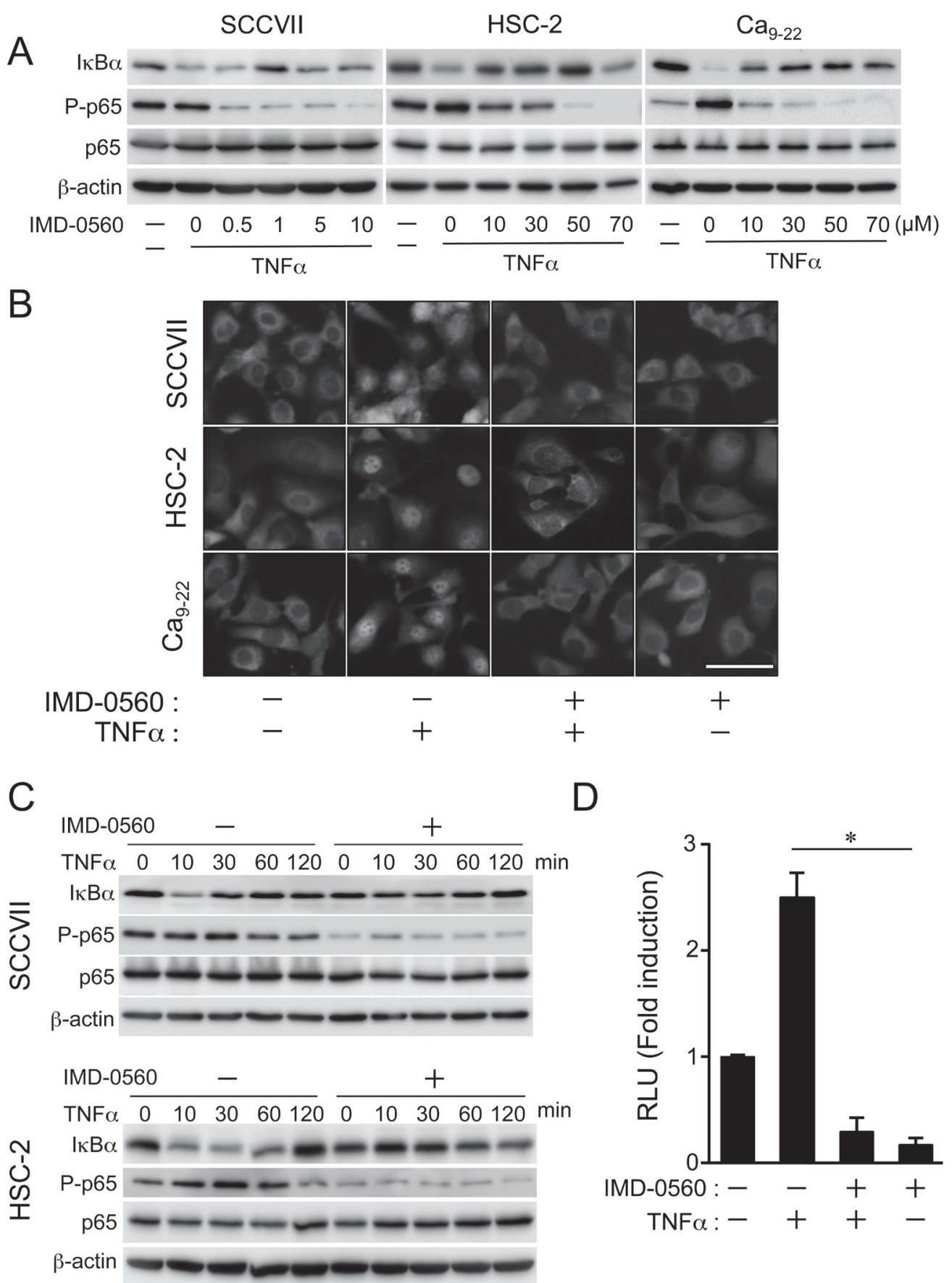

Figure 1: IMD-0560 inhibits TNF $\alpha$-induced p65 phosphorylation and IкB $\alpha$ degradation in OSCC cells. (A) SCCVII, HSC-2 and $\mathrm{Ca}_{9-22}$ cells were pretreated with various concentrations of IMD-0560 for $120 \mathrm{~min}$ and then treated with TNF $\alpha$ (10 ng/ml) for 15 min. p65 phosphorylation and I $\mathrm{B} \alpha \alpha$ degradation were examined via Western blot. $\beta$-actin was used as a loading control. Similar results were obtained in three independent experiments. (B) SCCVII, HSC-2 and $\mathrm{Ca}_{9-22}$ cells were pretreated with or without IMD-0560 (1 or $\left.10 \mu \mathrm{M}\right)$ for $120 \mathrm{~min}$ and then further treated with or without $\mathrm{TNF} \alpha(10 \mathrm{ng} / \mathrm{ml})$ for $30 \mathrm{~min}$. Then, the cells were fixed and incubated in an anti-p65 antibody, followed by incubation in Alexa Fluor 430-conjugated anti-rabbit IgG. The subcellular localization of Alexa Fluor 430-labeled p65 was determined via fluorescence microscopy (magnification 200x). Bar $=50 \mu \mathrm{m}$. Similar results were obtained in three independent experiments. (C) SCCVII and HSC-2 cells were pretreated or without IMD-0560 (1 or $10 \mu \mathrm{M})$ for 120 min and then treated with TNF $\alpha$ $(10 \mathrm{ng} / \mathrm{ml})$ for the indicated periods. p65 phosphorylation and IкB $\alpha$ degradation were examined via Western blot. $\beta$-actin was used as a loading control. Similar results were obtained in three independent experiments. (D) SCCVII cells were transiently transfected with a PBIIx reporter, pretreated with or without IMD-0560 $(1 \mu \mathrm{M})$ for $120 \mathrm{~min}$ and then treated with or without TNF $\alpha(10 \mathrm{ng} / \mathrm{ml}) \mathrm{for} 8 \mathrm{hrs}$. The cells were assessed for luciferase activity after $8 \mathrm{hrs}$. The data are expressed as the mean $\pm \mathrm{SD}(\mathrm{n}=3)$. ${ }^{*} p<0.01$. Similar results were obtained in three independent experiments. 


\section{Inhibitory effect of IMD-0560 on the invasion of OSCC cells}

TNF $\alpha$ markedly enhanced the invasion of SCCVII and HSC-2 cells but not $\mathrm{Ca}_{9-22}$ cells (Figures $2 \mathrm{~A}$ and $2 \mathrm{~B}$ ). Pretreatment with IMD-0560 strongly inhibited TNFainduced cell invasion, suggesting that NF- $\mathrm{\kappa B}$ activation plays a role in OSCC invasion. The viability of the cells treated with IMD-0560 for up to $24 \mathrm{hrs}$ was compatible with that of untreated cells (Supplementary Figure S1).

$\mathrm{TNF} \alpha$-induced cell invasion across a gelatincoated membrane may partially occur due to the activity of gelatinase released from OSCC cells. Therefore, we investigated the effects of IMD-0560 on the production of 2 major gelatinases, MMP-2 and MMP-9, via gelatin zymography. TNF $\alpha$ induced $92 \mathrm{kDa}$ gelatinase activity in SCCVII and HSC-2 cells, and this $92 \mathrm{kDa}$ gelatinase corresponded to MMP-9; however, TNF $\alpha$ did not affect the release of MMP-2 (Figure 2C). Pretreatment with IMD-

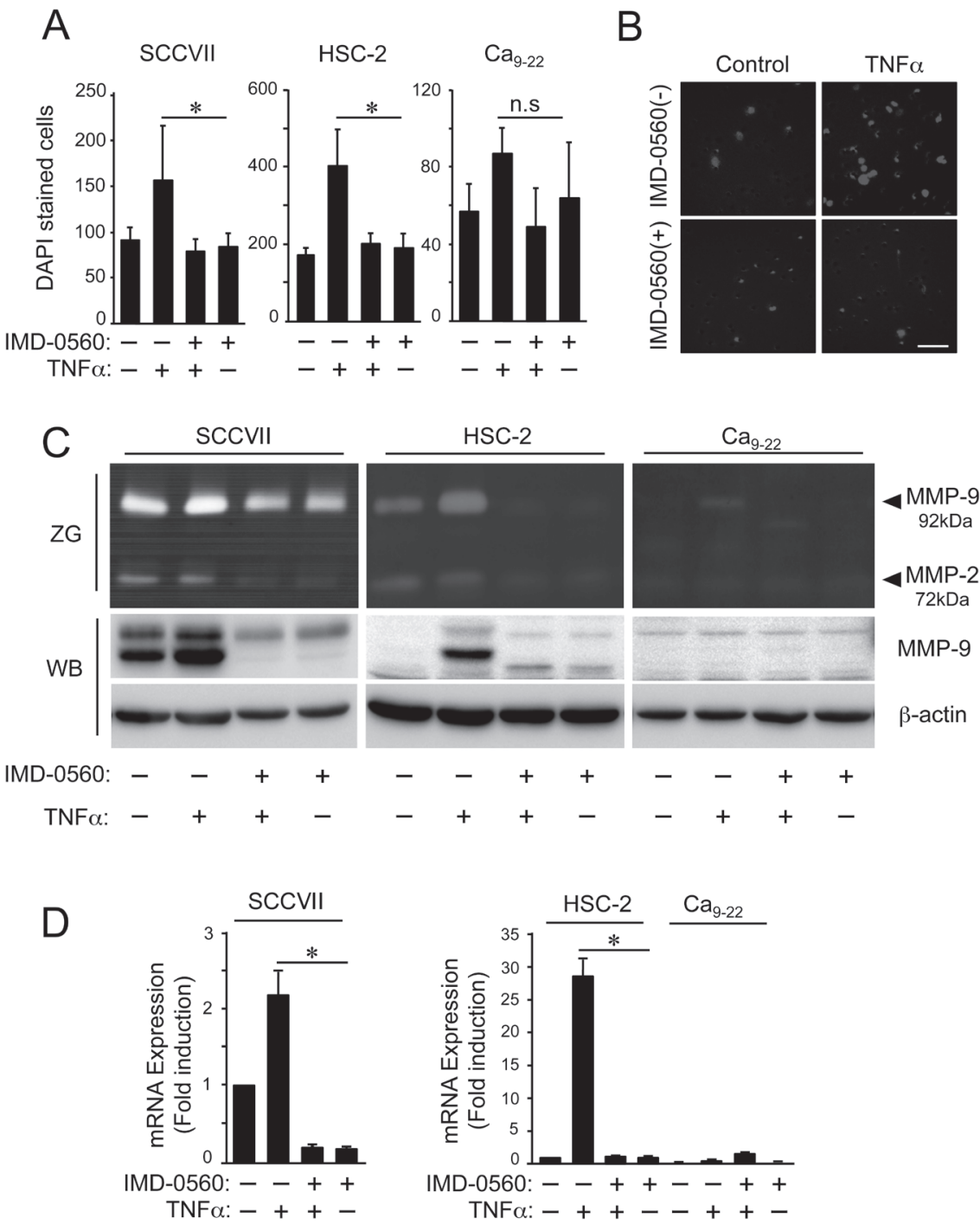

Figure 2: IMD-0560 inhibits cell invasion and MMP9 activity in OSCC cells. (A) The cells suspended in serum-free DMEM were seeded in the upper chamber above a gelatin-coated porous membrane. IMD-0560 (1 or $10 \mu \mathrm{M})$ was placed in the upper chamber 2 hrs prior to TNF $\alpha$ treatment, and $10 \mathrm{ng} / \mathrm{ml} \mathrm{TNF} \alpha$ was placed in the lower chamber, followed by incubation for $24 \mathrm{hrs}$. Then, the cells attached to the upper surface of the membrane were scraped off, and the cells that migrated to the lower surface were fixed and stained with DAPI and then quantified. The data are expressed as the mean $\pm \mathrm{SD}(\mathrm{n}=3)$. ${ }^{*} p<0.01$. Similar results were obtained in three independent experiments. (B) A representative image of each group in SCCVII cells is shown (magnification 200x). Bar $=50 \mu \mathrm{m}$. Similar results were obtained in three independent experiments. (C) The cells were incubated in serum-free DMEM for $24 \mathrm{hrs}$ in the presence or absence of TNF $\alpha$ pretreated with or without IMD-0560 ( 1 or $10 \mu \mathrm{M})$. The conditioned media were analyzed via gelatin zymography (ZG). The identical conditioned media were used for Western blot analysis (WB) to detect MMP-9. (D) The cells were pretreated with or without IMD-0560 (1 or $10 \mu \mathrm{M}$ ), followed by treatment with or without TNF $\alpha$. Total RNA was isolated, and the $m m p-9$ and $\beta$-actin mRNA levels were analyzed via real-time $\mathrm{PCR}$. The data represent the mean $\pm \mathrm{SD}$ of the expression levels of $m m p-9$ relative to $\beta$-actin $(\mathrm{n}=3) .{ }^{*} p<0.01$. Similar results were obtained in three independent experiments. 
0560 suppressed MMP-9 activity by inhibiting MMP-9 expression (Figure 2D). Although TNF $\alpha$ slightly induced MMP-9 activity, but not MMP-2 activity in SCCVII and HSC-2 cells, TNF $\alpha$ failed to induce MMP-9 expression in $\mathrm{Ca}_{9-22}$ cells (Figure 2D). TNF $\alpha$ strongly increased the mRNA level of MMP-9, and IMD-0560 inhibited the TNF $\alpha$-induced increase in MMP-9 mRNA expression.

\section{Early treatment with IMD-0560 inhibited bone invasion by SCCVII cells}

To examine the inhibitory effects of IMD-0560 on bone invasion by SCCVII cells using mouse bone invasion model, we first treated the animals with IMD05603 times per week for 3 weeks beginning 1 week after SCCVII injection (Figure 3A). Although the average body weight was slightly reduced in the control group, it was
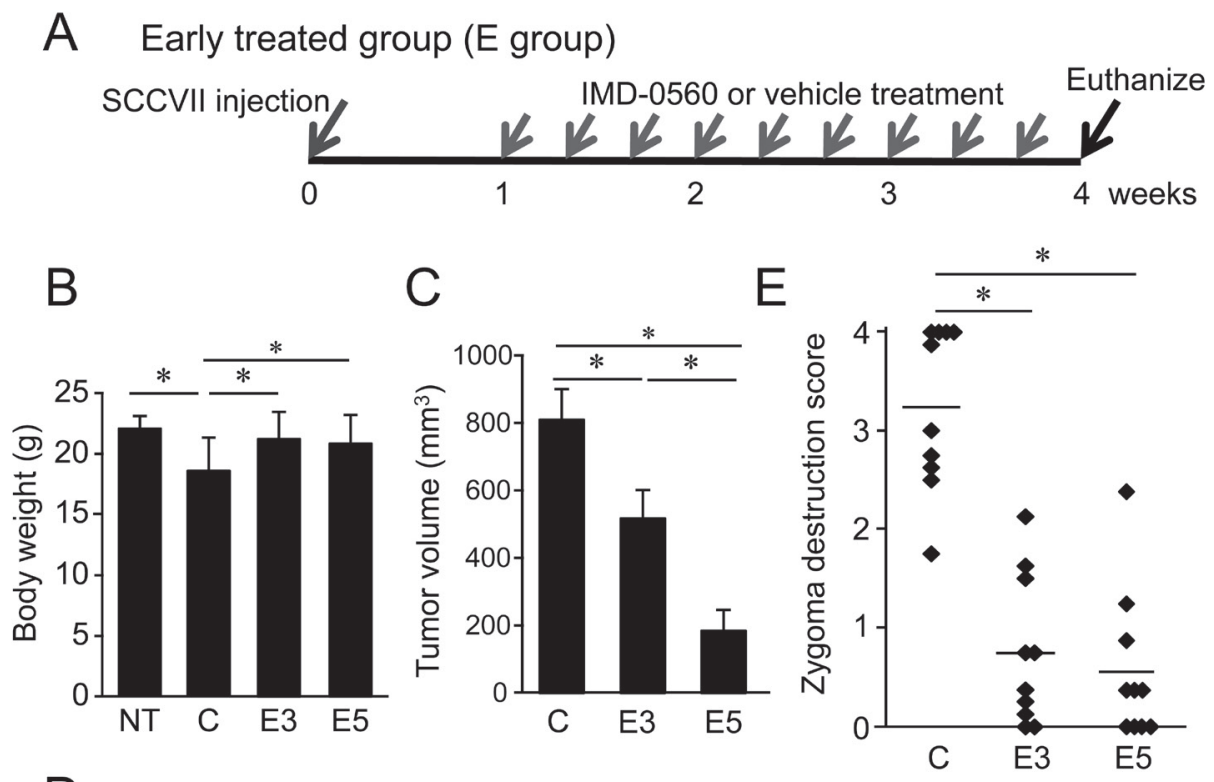

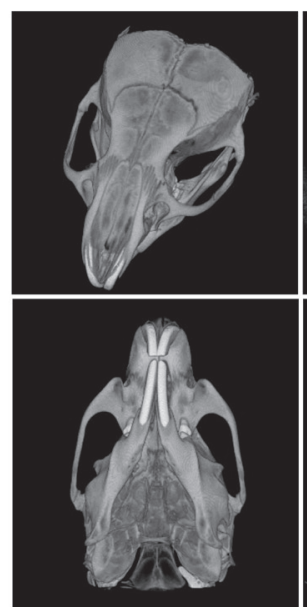

No Tumor

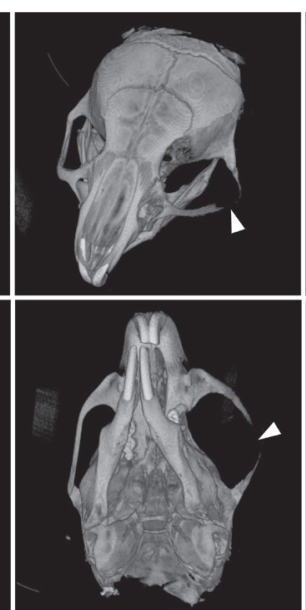

Control

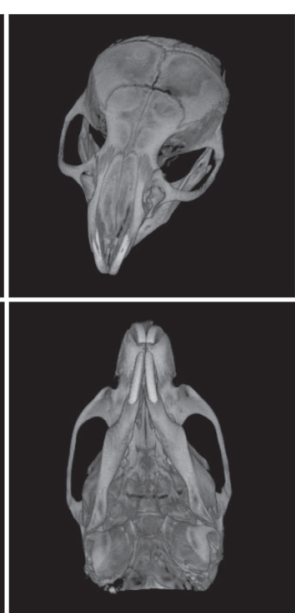

E3

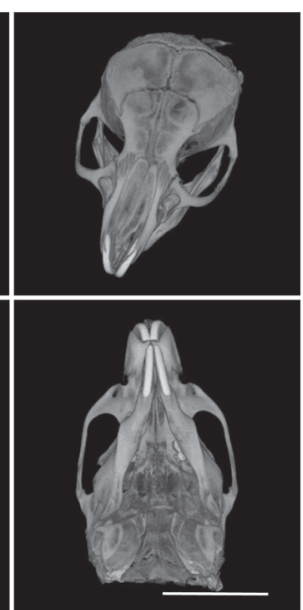

E5

Figure 3: Early treatment with IMD-0560 inhibited bone invasion by SCCVII cells. SCCVII cells were injected into the left masseter region of 8 - to 10 -week-old male $\mathrm{C} 3 \mathrm{H} / \mathrm{HeN}$ mice. One week after injection, the mice were locally treated with vehicle $(50 \mu 1$ of CMC: control, $\mathrm{n}=10$ ) or IMD-0560 ( 3 or $5 \mathrm{mg} / \mathrm{kg}$ in $50 \mu \mathrm{l}$ of CMC, $\mathrm{n}=10$ each) 3 times per week for 3 weeks. (A) Protocol of IMD-0560 treatment. (B) In the SCCVII cell mouse model, the body weights were measured 28 days after tumor inoculation. Mice treated with CMC alone served as controls. NT: no tumor inoculation, C: control, E3: mice treated with IMD-0560 at $3 \mathrm{mg} / \mathrm{kg}$, E5: mice treated with IMD0560 at $5 \mathrm{mg} / \mathrm{kg}$. (C) The tumor volume was assessed using calipers and was calculated using the following formula: width ${ }^{2} \mathrm{x}$ length $\mathrm{x} 0.52$. The data represent the mean $\pm \mathrm{SD} ;{ }^{*} p<0.05$. (D) Reconstructed $\mu$-CT images of zygoma destruction in the control and IMD-0560-treated mice. The arrowheads indicate destruction of the zygoma, and the arrow indicates a fracture line. Bar: $8 \mathrm{~mm}$. (E) The severity of zygoma destruction was assessed based on clinical scoring of the control and IMD-0560-treated mice. $* p<0.01$. 
unchanged in the IMD-0560-treated groups compared with those of the no injection group (Figure 3B). The tumor size was reduced in the IMD-0560-treated groups in a dose-dependent manner, and no tumor was detected in some mice treated with $5 \mathrm{mg} / \mathrm{kg}$ IMD-0560 (Figure 3C).

The $\mu$-CT images revealed the typical extent of bone invasion in all groups (Figure 3D). Figure 3E shows the zygomatic bone destruction score. In the control group, the zygoma and the mandible were severely destroyed (Figures 3D and 3E). In some IMD-0560-treated mice, we observed fractures of the zygoma. However, zygoma destruction was significantly suppressed in the IMD-0560treated groups compared to the control groups. Although the tumor size in the $5 \mathrm{mg} / \mathrm{kg}$ IMD-0560-treated group was smaller than that of the $3 \mathrm{mg} / \mathrm{kg}$ IMD-0560-treated group, the inhibitory effect of each treatment on zygoma destruction was similar (Figures 3D and 3E).

Histological analysis revealed resorption of the mandibular bone, including irregularities in the bone surface and an area of osteoclast occupation at the tumor/ bone interface, in the control group (Figure 4A, upper and middle panels). The tumors were barely detected in the $5 \mathrm{mg} / \mathrm{kg}$ IMD-0560-treated group (Figure 4A). Many osteoclasts were easily identified in the control group after TRAP staining (Figures 4A, middle panels, and 4B). A few osteoclasts were detected in the $3 \mathrm{mg} /$ kg IMD-0560-treated group, and none were detected in the $5 \mathrm{mg} / \mathrm{kg}$ IMD-0560-treated group (Figures 4A, middle panels, and 4B). In addition to the SCCVII cells that express RANKL, RANKL-positive osteoblastic cells were located at the interface between the bone and the SCCVII cells, presumably reflecting an increase in the number of osteoclasts in the control group (Figure 4A, bottom panels). RANKL expression in both the SCCVII cells and the osteoblastic cells was reduced in the $3 \mathrm{mg} / \mathrm{kg}$ IMD-0560-treated group (Figure 4A, bottom panels). No RANKL-positive cells were detected near the bone surface in the $5 \mathrm{mg} / \mathrm{kg}$ IMD-0560-treated group. Furthermore, IMD-0560 suppressed RANKL expression in osteoblasts and RANKL-induced osteoclastogenesis in vitro (Supplementary Figure S2).

The tumor size in the IMD-0560-treated mice was decreased (Figure 3C), suggesting that IMD-0560 treatment inhibited cell proliferation and/or cell death compared to the control treatment. Immunoreactivity for $\mathrm{Ki}-67$, a marker of proliferation, was localized to the cell nuclei. IMD-0560 treatment significantly reduced the number of Ki-67-positive SCCVII cells compared to the control treatment (Figures 4C and 4D), suggesting that IMD-0560 treatment inhibited tumor cell proliferation. IMD-0560 suppressed cell proliferation, suggesting that the IMD-0560-induced inhibition of NF$\kappa \mathrm{B}$ directly suppressed the proliferation of SCCVII cells (Supplementary Figure S3). Next, we examined whether IMD-0560 treatment increased SCCVII cell death in vivo. Most tumor cells were intact in the control group, whereas in the $3 \mathrm{mg} / \mathrm{kg}$ IMD-0560-treated group, some foci of necrotic cells, characterized by an eosinophilic cytoplasm and nuclear changes such as pyknosis, karyorrhexis and karyolysis, were detected. The number of TUNEL-positive apoptotic cells was increased in the $3 \mathrm{mg} / \mathrm{kg}$ IMD-0560treated group (Supplementary Figure S4). Carcinoma cells were nearly absent from the site of cell injection in the 5 $\mathrm{mg} / \mathrm{kg}$ IMD-0560-treated group (Figure 4E). Furthermore, we assessed the number of apoptotic cells using Annexin $\mathrm{V}$ and PI staining in vitro. IMD-0560 induced apoptosis, suggesting that the IMD-0560-induced inhibition of NF- $\kappa \mathrm{B}$ directly activated apoptosis in SCCVII cells (Supplementary Figure S1). IMD-0560 treatment also reduced the number of MMP-9-positive SCCVII cells (Figures 4F and 4G).

\section{IMD-0560 injection was useful for the treatment of bone invasion by SCCVII cells}

To further examine whether IMD-0560 local injection is useful for the treatment of bone invasion, we treated animals with IMD-0560 3 times per week for 2 weeks beginning 2 weeks after SCCVII injection (Figure 5A). Before IMD-0560 injection, we detected tumor growth in all mice. Although the average body weight was slightly reduced in the control group, it was unchanged in the IMD-0560-treated groups compared with the no injection group (Figure 5B). The tumor size was reduced by up to half in the IMD-0560-treated groups, but there was no difference between the $3 \mathrm{mg} / \mathrm{kg}$ and $5 \mathrm{mg} / \mathrm{kg}$ IMD0560-treated groups (Figure 5C).

The $\mu$-CT images revealed severe destruction of the zygoma and the mandible in the control mice (Figure 5D). In some $3 \mathrm{mg} / \mathrm{kg}$ IMD-0560-treated mice, we detected fractures of the zygoma. However, zygoma destruction was significantly suppressed in the IMD-0560-treated groups compared to the control groups. Treatment with $5 \mathrm{mg} / \mathrm{kg}$ IMD-0560 prevented zygoma destruction more effectively than treatment with $3 \mathrm{mg} / \mathrm{kg}$ IMD-0560 (Figures 5D and 5E).

Histological analysis revealed of the mandibular bone, including irregularities in the bone surface and an area of osteoclast occupation at the tumor/bone interface, in the control group and some of the animals in the $3 \mathrm{mg} /$ $\mathrm{kg}$ IMD-0560-treated group. In the $5 \mathrm{mg} / \mathrm{kg}$ IMD-0560treated group, tumors were detected far from mandibular bone, but they were not attached to the bone surface, and the mandibular surface was smooth (Figure 6A, upper panels). Many osteoclasts were easily identified in the control group, and osteoclasts were observed along the resorbed lacunae in the $3 \mathrm{mg} / \mathrm{kg}$ IMD-0560-treated group (Figures 6A, middle panels and 6B). Few osteoclasts were detected in the $5 \mathrm{mg} / \mathrm{kg}$ IMD-0560-treated group (Figures 6A, middle panels and 6B). The SCCVII cells and the osteoblastic cells located at the interface between the 

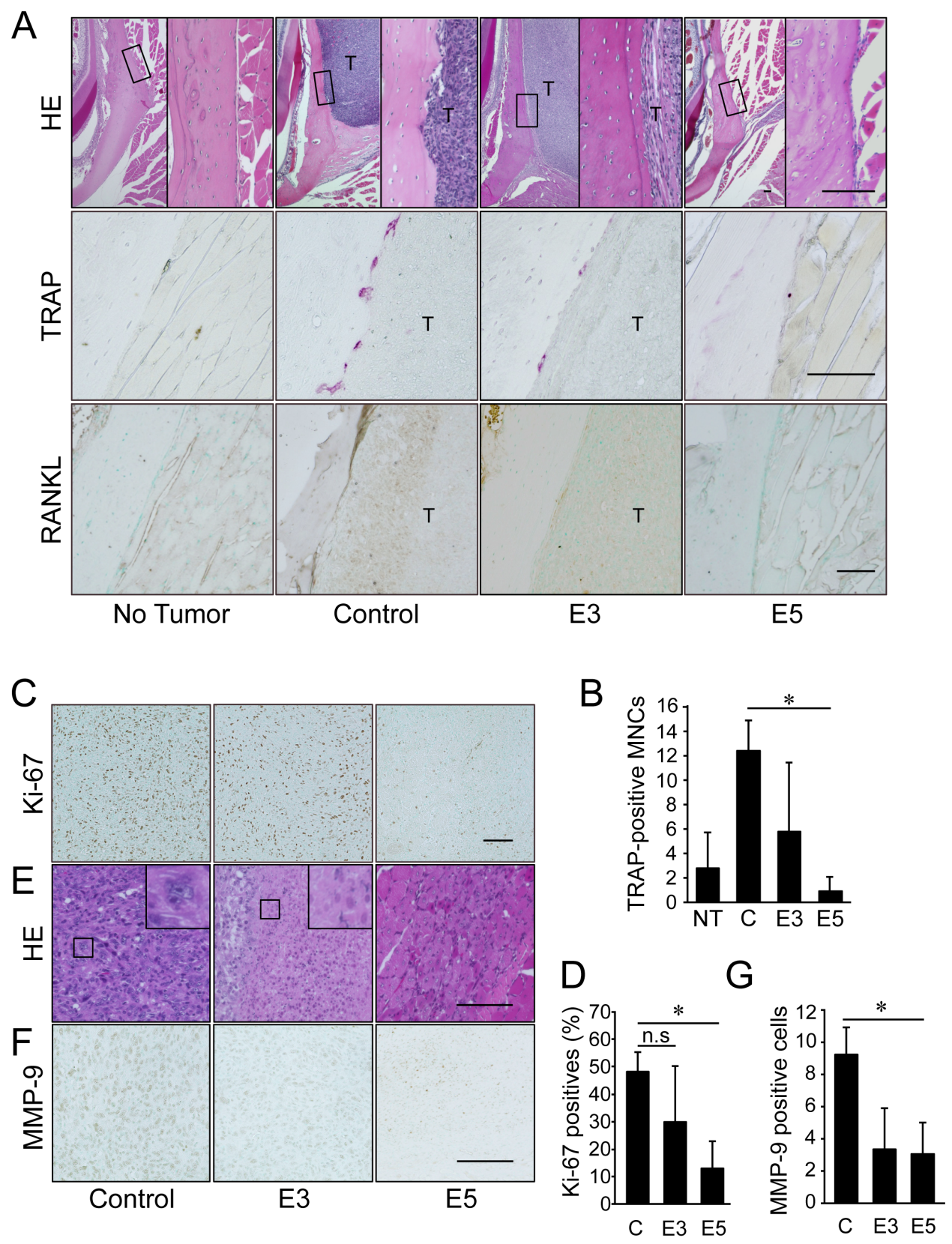

Figure 4: Early treatment with IMD-0560 reduced bone invasion by inhibiting osteoclastogenesis. Twenty-eight days after tumor inoculation, the tissues were fixed in 3.7\% formaldehyde, decalcified in 10\% EDTA, sectioned in the coronal axis and stained with H\&E (upper panels), TRAP (middle panels) or RANKL (lower panels). Mice treated with CMC alone served as controls. NT: no tumor inoculation, C: control, E3: mice treated with IMD-0560 at $3 \mathrm{mg} / \mathrm{kg}$, E5: mice treated with IMD-0560 at $5 \mathrm{mg} / \mathrm{kg}$. (A) Upper panels: Original magnification 40x. Bar=100 $\mu \mathrm{m}$. Middle panels: Original magnification 400x. Bar=100 $\mu \mathrm{m}$. Lower panels: Some specimens from each group were processed for immunohistochemical staining with an anti-RANKL antibody. Original magnification 200x. T: tumor. Bar $=100 \mu \mathrm{m}$. Mice treated with CMC alone served as controls. (B) In each specimen, 5 tumor fields were randomly selected, and the number of TRAP ${ }^{+} \mathrm{MNCs}$ was counted. The data are expressed as the mean $\pm \mathrm{SD}$ of the number of TRAP $\mathrm{MNCs}^{+} / \mathrm{bone}$ surface $\left(\mathrm{mm}^{2}\right) /$ section $(\mathrm{n}=10) . * p<0.05$. Similar results were obtained in three independent experiments. (C) A representative photograph of Ki-67 staining in a tumor from the control and IMD-0560-treated groups in vivo. Ki-67-positive SCCVII cells were clearly identifiable based on brown staining (magnification 200x). Bar=100 $\mu \mathrm{m}$. (D) The number of Ki-67-positive cells was counted in 5 randomly selected fields of each specimen. The data are expressed as the numbers of Ki-67-positive cells/total number of tumor cells/field. ${ }^{*} p<0.05$. (E) A representative photograph of H\&E staining in the tumor of control and IMD-0560-treated groups in vivo (magnification 400x). Bar=100 $\mu \mathrm{m}$. (F) A representative photograph of MMP-9 staining of a tumor from the control and IMD-0560-treated groups in vivo. MMP-9-positive SCCVII cells were clearly identifiable based on brown staining (magnification 400x). Bar=100 $\mu \mathrm{m}$. (G) The number of MMP-9-positive cells were counted in 5 randomly selected fields of each tumor specimen. The data are expressed as the percentage of MMP-9-positive cells/total number of tumor cells/field. ${ }^{*} p<0.01$. 
bone and the SCCVII cells strongly expressed RANKL in the control group (Figure 6A, bottom panels). RANKL expression in both the SCCVII cells and the osteoblastic cells was reduced in the $3 \mathrm{mg} / \mathrm{kg}$ IMD-0560-treated group compared to the control group. No RANKL-positive cells were detected near the bone surface in the $5 \mathrm{mg} / \mathrm{kg}$ IMD0560-treated group (Figure 6A, bottom panels).

The number of Ki-67-positive cells in the tumors was similar between the $3 \mathrm{mg} / \mathrm{kg}$ IMD-0560-treated group and the control group. Treatment with the higher dose of
IMD-0560 strongly reduced the number of Ki-67-positive cells (Figures 6C and 6D). The tumor tissue was nearly intact in the control group, whereas small necrotic foci were detected in the $3 \mathrm{mg} / \mathrm{kg}$ IMD-0560-treated group. The tumor tissue in the $5 \mathrm{mg} / \mathrm{kg}$ IMD-0560-treated group was largely replaced by necrotic and granulated tissue (Figure 6E). Treatment with $3 \mathrm{mg} / \mathrm{kg}$ IMD-0560 failed to reduce the number of MMP-9-expressing tumor cells, but $5 \mathrm{mg} / \mathrm{kg}$ IMD-0560 greatly reduced the number of MMP9 -expressing tumor cells (Figures 6F and 6G).

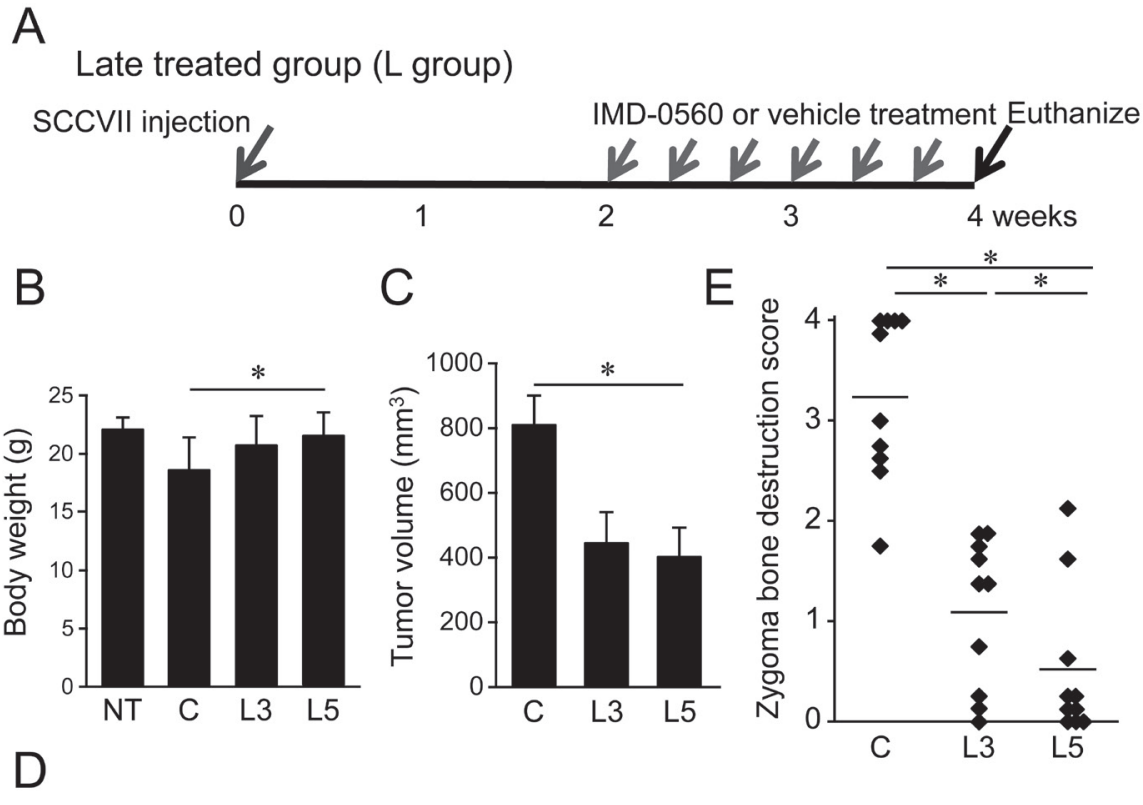

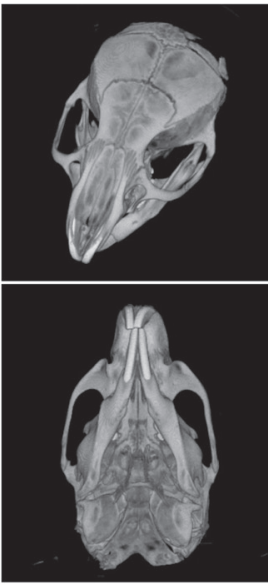

No Tumor

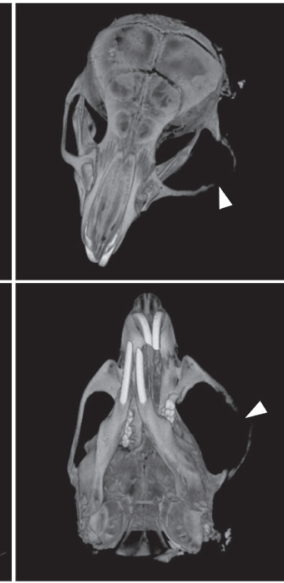

Control

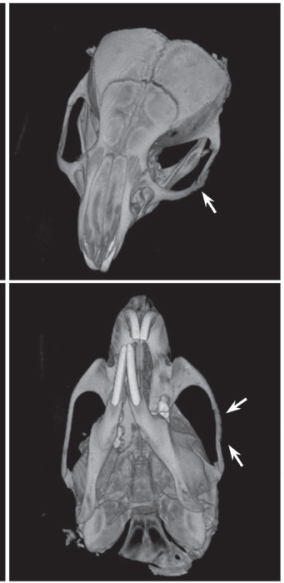

L3

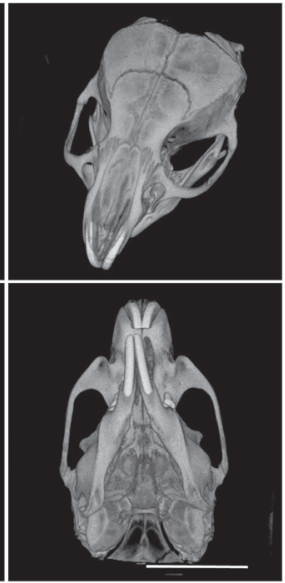

L5

Figure 5: IMD-0560 injection was useful for the treatment of bone invasion by SCCVII cells. SCCVII cells were injected into the left masseter region of 8 - to 10 -week-old male $\mathrm{C} 3 \mathrm{H} / \mathrm{HeN}$ mice. Two weeks after injection, the mice were treated locally with vehicle $(50 \mu \mathrm{l}$ of CMC, $\mathrm{n}=10)$ or IMD-0560 (3 or $5 \mathrm{mg} / \mathrm{kg}$ in $50 \mu \mathrm{l}$ of CMC, $\mathrm{n}=10) 3$ times per week for 2 weeks. (A) Protocol of IMD0560 treatment. (B) In the SCCVII cell mouse model, the body weights were measured 28 days after tumor inoculation. Mice treated with CMC alone served as controls. NT: no tumor inoculation, C: control, L3: mice treated with IMD-0560 at $3 \mathrm{mg} / \mathrm{kg}$, L5: mice treated with IMD-0560 at $5 \mathrm{mg} / \mathrm{kg}$. (C) The tumor volume was assessed using calipers and was calculated using the following formula: width ${ }^{2} \mathrm{x}$ length $x$ 0.52. Mice treated with PBS served as controls. The data represent the mean $\pm \mathrm{SD} ;{ }^{*} p<0.05$. (D) Reconstructed $\mu \mathrm{CT}$ images of zygoma destruction in the control and IMD-0560-treated mice. The arrowheads indicate destruction of the zygoma, and the arrow indicates a fracture line. Bar: $8 \mathrm{~mm}$. (E) The severity of zygoma destruction was assessed based on clinical scoring of the control and IMD-0560treated mice. ${ }^{*} p<0.05$. 

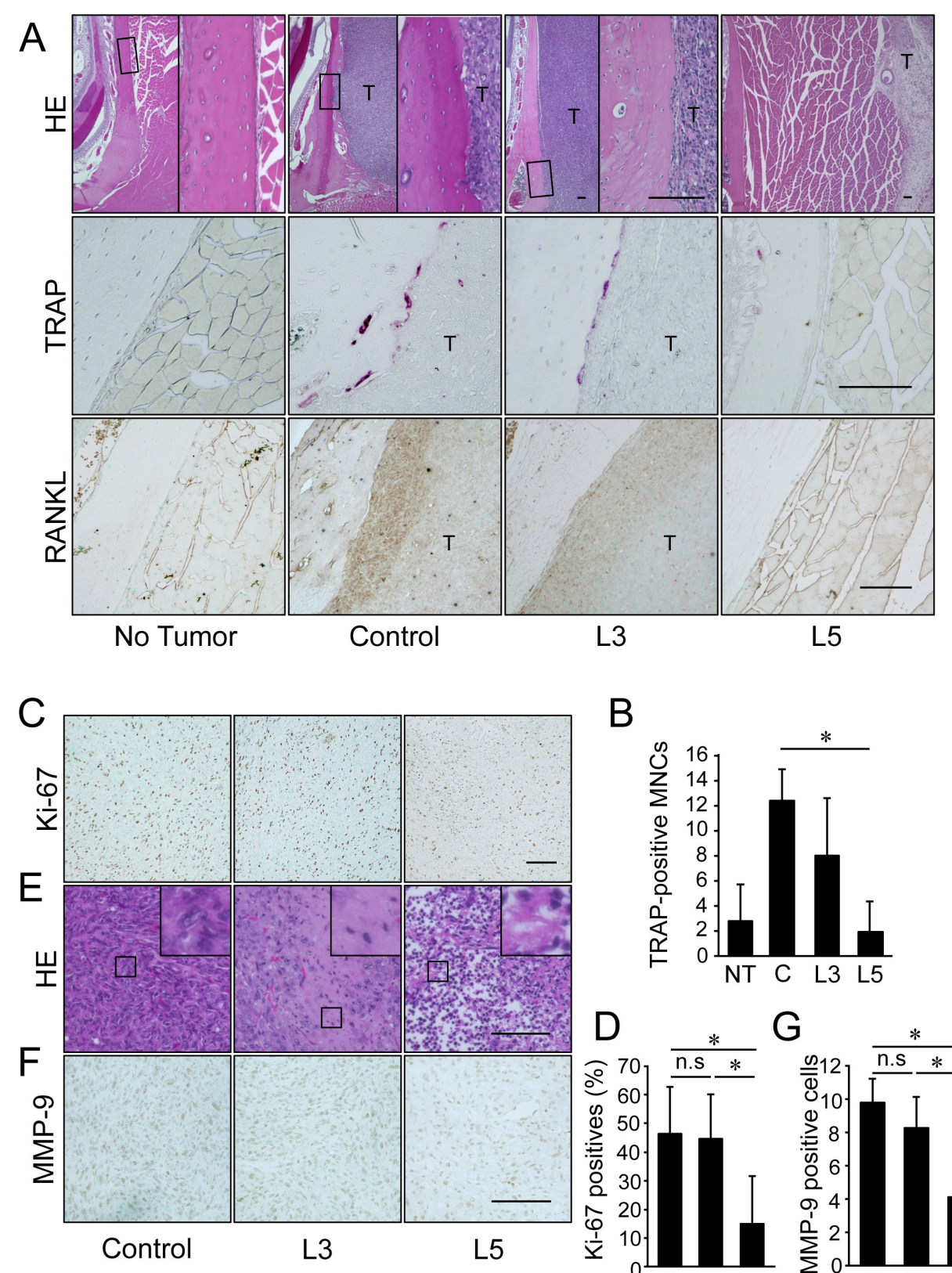

B
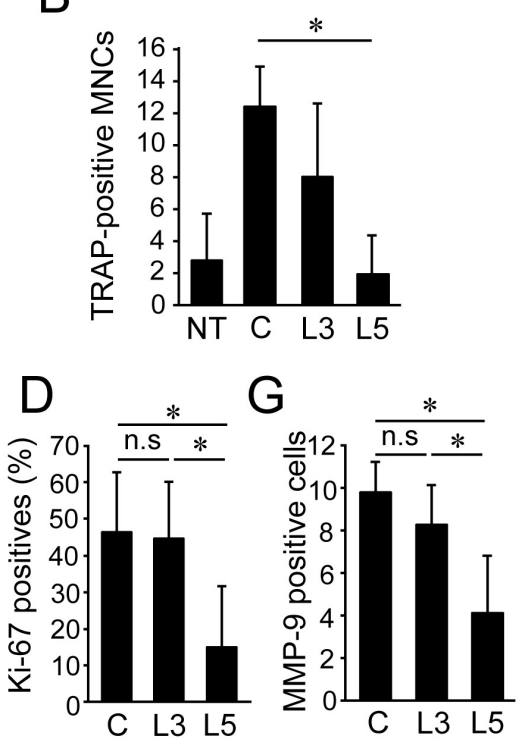

Figure 6: IMD-0560 injection was useful for the treatment of bone invasion by SCCVII cells via the inhibition of osteoclastogenesis. Twenty-eight days after tumor inoculation, the tissues were fixed in 3.7\% formaldehyde, decalcified in 10\% EDTA, sectioned in the facial axis and stained with H\&E (upper panels), TRAP (middle panels) or RANKL (lower panels). Mice treated with CMC alone served as controls. NT: no tumor inoculation, C: control, L3: mice treated with IMD-0560 at $3 \mathrm{mg} / \mathrm{kg}$, L5: mice treated with IMD-0560 at $5 \mathrm{mg} / \mathrm{kg}$. (A) Upper panels: Original magnification 40x. Bar=100 $\mu \mathrm{m}$. Middle panels: Original magnification 400x. Bar=100 $\mu \mathrm{m}$. Lower panels: Some specimens from each group were processed for immunohistochemical staining with an anti-RANKL antibody. Original magnification 200x. T: tumor. Bar=100 $\mu \mathrm{m}$. (B): In each specimen, 5 tumor fields were randomly selected, and the number of $\mathrm{TRAP}^{+} \mathrm{MNCs}$ was counted. The data are expressed as the mean $\pm \mathrm{SD}$ of the number of TRAP ${ }^{+} \mathrm{MNCs} /$ bone surface $\left(\mathrm{mm}^{2}\right) / \mathrm{section}(\mathrm{n}=10)$. ${ }^{*} p<0.05$. Similar results were obtained in three independent experiments. (C): A representative photograph of Ki-67 staining in a tumor from the control and IMD-0560-treated groups in vivo. Ki-67-positive SCCVII cells were clearly identifiable based on brown staining (magnification 200x). Bar=100 $\mu \mathrm{m}$. (D) The number of Ki-67-positive cells were counted in 5 randomly selected fields of each specimen. The data are expressed as the number of Ki-67-positive cells/total number of tumor cells/field. ${ }^{*} p<0.05$. (E) A representative photograph of $\mathrm{H} \& \mathrm{E}$ staining of a tumor from the control and IMD-0560-treated groups in vivo (magnification 400x). Bar=100 $\mu \mathrm{m}$. (F) A representative photograph of MMP-9 staining of a tumor from the control and IMD-0560-treated groups in vivo. MMP-9-positive SCCVII cells were clearly identifiable based on brown staining (magnification 400x). Bar=100 $\mu \mathrm{m}$. (G) The number of MMP-9-positive cells was counted in 5 randomly selected fields of each tumor specimen. The data are expressed as the percentage of MMP-9-positive cells/total number of tumor cells/field. ${ }^{*} p<0.01$. 


\section{DISCUSSION}

Aberrant NF- $\kappa \mathrm{B}$ activity is implicated in many cancers, including OSCC, and contributes to the acquisition of malignant characteristics, such as increased cell invasion, cell survival, chemoresistance, and angiogenesis [13-15]. The therapeutic potential of IKK $\beta$ dependent NF- $\mathrm{KB}$ pathway disruption in cancers has been extensively studied using biochemical approaches $[19$, 20]. The dominant negative form of IKK $\beta$, which lacks conserved lysine residue that is necessary for its catalytic activity, or non-degradable I $\mathrm{B} \alpha$, which lacks its serine phosphorylation sites, reduced inflammatory cytokine expression and tumor growth in vitro and in vivo [21, 25 , 26], suggesting that IKK $\beta$ inhibition represents a very promising therapeutic strategy for cancer. To date, several pharmacological inhibitors of NF- $\kappa \mathrm{B}$ have been developed, and these inhibitors have been demonstrated to effectively reduce cancer cell growth and invasion $[13,14]$. Additionally, we have shown that a selective inhibitor of NF- $\mathrm{kB}, \mathrm{NBD}$ peptide, inhibited bone invasion by SCCVII cells via the suppression of osteoclastic bone resorption, increased apoptosis, and suppressed the proliferation of SCCVII cells [21]. However, it is very difficult to apply this laboratory reagent to clinical use.

IMD-0560 and its prodrug IMD-2560 are recently synthesized agents that inhibit IKK $\beta$ activity under inflammatory stimuli and the subsequent production of cytokines [19-24]. IMD-0560 potently inhibited TNF $\alpha$-induced IL-6 production in human fibroblast-like synoviocytes derived from rheumatoid arthritis patients (HFLS-RA) cells and TNF $\alpha$-induced NF- $\mathrm{kB}$ activation in HEK293T cells without causing cell toxicity, although its potency greatly varies depending on the cell type, incubation time and other conditions [22-24]. In this study, we used IMD-0560 from 1 to $10 \mu \mathrm{M}$ to inhibit MMP-9 activity or p65 phosphorylation. The in vivo efficiency of IMD-0560 has been demonstrated, as intraperitoneal injection of DBA $/ 1 \mathrm{~J}$ mice with 1 or $3 \mathrm{mg} / \mathrm{kg}$ IMD-0560 every 48 hours beginning at the first immunization resulted in a significant and dose-dependent reduction in the incidence, severity, and pathological abnormalities of collagen-induced arthritis [22]. Moreover, IMD-0560 significantly improved cardiac function in a rat myocardial ischemia model [23]. Furthermore, a phase I study has been completed using IMD-2560, which is reportedly under assessment for rheumatoid arthritis [20]. These results led us to investigate whether IMD-0560 inhibits bone invasion by OSCC using an animal model.

Bone invasion by OSCC consists of a complex, multistep cascade of events, and these events are regulated by a wide variety of molecules that contribute to cell invasion of jaw bones, including the degradation of the extracellular matrix of gingiva and osteoclastogenesis $[4,5]$. Several in vitro and animal experiments using OSCC cells have shown that tumor cells produce several cytokines, including interleukin-6 (IL-6), IL-11, TNF $\alpha$ and parathyroid hormone-related protein (PTHrP). These cytokines regulate the expression of RANKL and osteoprotegerin $[9,10]$. In this model, RANKL expression was observed in both SCCVII cells and osteoblastic cells that faced the bone surface. IMD-0560 suppressed RANKL expression in both SCCVII cells and osteoblastic cells might be due to induce SCCVII apoptosis or to lead less production of cytokines, which induce RANKL.

MMPs, such as MMP-1, -2, -9 and -14, are involved in the invasive properties of OSCC via the degradation of the extracellular matrix [27], and MMP expression is regulated by NF- $\kappa \mathrm{B}$ [28]. A previous report showed that the NF- $\kappa \mathrm{B}$ binding site in the MMP-9 promoter region in human fibroblasts is necessary for the inflammatory cytokine-mediated induction of MMP-9 expression, and we previously reported that the expression and activity of MMP-9, but not MMP-2, are regulated by NF$\kappa \mathrm{B}[29]$. TNF $\alpha$ stimulated the invasion of HSC-2 and SCCVII cells, but not $\mathrm{Ca}_{9-22}$ cells, by increasing MMP9 mRNA and protein expression and activity. $\mathrm{Ca}_{9-22}$ cells display limited invasion potential and MMP-9 protein expression [30]. IMD-0560 treatment suppressed MMP9 activity by inhibiting MMP-9 mRNA expression, suggesting that IMD-0560 suppressed MMP-9 activity at the transcriptional level. In support of this conclusion, injection of IMD-0560 reduced the number of MMP-9positive SCCVII cells in vivo. IMD-0560 treatment also suppressed MMP-2 production in SCCVII and HSC-2 cells. Although IMD-0560 did not notably affect cell viability, it might slightly damage these cells.

The most important aspect of this study compared with former experiments that used other pharmacological NF- $\mathrm{kB}$ inhibitors is that the inhibitor used in this study effectively prevented bone invasion upon initiation of 5 $\mathrm{mg} / \mathrm{kg}$ IMD-0560 injection at a relatively advanced stage of tumor growth. In the previous study and this study, we initiated the injection of NBD peptide or IMD-0560 immediately after tumor implantation. Although injection of NBD peptide or IMD-0560 sufficiently inhibited bone invasion by SCCVII cells in these experiments, patients hardly recognize any sign of ill-health at the early stage of OSCC in clinical practice. Thus, we used a "late treatment model" in which IMD-0560 injection was initiated after confirming that the tumor had become large. Treatment with $5 \mathrm{mg} / \mathrm{kg}$ IMD-0560 reduced the tumor size by up to half, but zygoma destruction was sufficiently blocked. Histological analysis revealed the tumor, but it appeared necrotic and did not reach the bone surface. Furthermore, cell proliferation and RANKL and MMP-9 expression in SCCVII cells were strongly inhibited by treatment with $5 \mathrm{mg} / \mathrm{kg}$ IMD-0560. So far, severe side effects of IMD treatment have not been reported during the phase I clinical trial [20]. Since it is generally agreed that patients with mandibular invasion should be treated surgically, these results indicate that a patient's burden 
might be mitigable, if the area of a surgical resection could be smaller after IMD-0560 treatment. Although we alternatively initiated $5 \mathrm{mg} / \mathrm{kg}$ IMD-0560 injection 3 weeks after SCCVII injection, when the tumor cells have invaded the bone, this treatment failed to prevent death because tumor cell growth was too rapid to control in this experiment (data not shown). It is likely that other pathways independent of the IKK $\beta-\mathrm{NF}-\kappa \mathrm{B}$ pathway were activated before administering IMD-0560.

In conclusion, it is noteworthy that NF- $\kappa \mathrm{B}$ activity increased in association with the enhancement of the bone invasive potential of OSCC. Selective inhibition of NF$\kappa \mathrm{B}$ activation using the novel IKK $\beta$ inhibitor IMD-0560 reduced bone invasion in an animal model. In the case of mandibular bone invasion, it is possible to locally treat cancer with IMD-0560 to avoid any unexpected severe side effects because OSCC cells invade from the cortical bone and because the tumor and defect are at the surface of the body. Previous reports have demonstrated the safety of IMD-0560 administration [22-24]. Similar results demonstrated that IMD-0560 treatment does not affect the proliferation of cells in the basal and parabasal layers of the tongue (Supplementary Figure S5), suggesting that IMD-0560 treatment specifically affects tumor cells. Thus, upon the establishment of a suitable protocol for IMD0560 treatment, our results will provide a new potential compound for the treatment of bone invasion by OSCC.

\section{MATERIALS AND METHODS}

All protocols for the present experiments were reviewed and approved by the Council on Animal Care at Kyushu Dental University (Approval number 13-006).

\section{Reagents}

The anti-p65 (sc-109), anti-IאB $\alpha$ (sc-371), antiRANKL (sc-7628) and anti-rabbit IgG (sc-2004) antibodies were obtained from Santa Cruz Biotechnology (Santa Cruz, CA, USA). The anti-phosphorylated p65 (Serine 536) (\#3031) and anti-mouse IgG antibodies were obtained from Cell Signaling (Beverly, MA, USA) and Amersham Bioscience (Piscataway, NJ, USA), respectively. The anti-rat matrix metalloproteinase-9 (MMP-9) antibody (AB19016) was obtained from Millipore (Billerica, MA, USA). The anti- $\beta$-actin antibody (AC-15) was purchased from Sigma-Aldrich (St. Louis, MO, USA).

\section{Cell culture}

The human OSCC cell lines used in our study were HSC-2 and $\mathrm{Ca}_{9-22}$, which were purchased from the Japanese Collection of Research Bioresources (JCRB) Cell Bank (Tokyo, Japan). SCCVII cells, derived from a mouse OSCC cell line, were cultured in Dulbecco's modified Eagle's medium (DMEM) containing 5\% fetal bovine serum (FBS), 100 units/ml penicillin, and 100 $\mathrm{mg} / \mathrm{ml}$ streptomycin (Sigma-Aldrich) in a humidified atmosphere containing $5 \% \mathrm{CO}_{2}$ at $37^{\circ} \mathrm{C}$.

\section{Western blot}

For immunoblotting, whole-cell lysates were resolved on SDS polyacrylamide gels, transferred to PVDF membranes and incubated at $4{ }^{\circ} \mathrm{C}$ overnight in antibodies diluted to $1: 1,000$ in a $5 \%$ dry milk or bovine serum albumin (BSA) solution containing $0.01 \%$ azide in TTBS (10 mM Tris-HCl, $50 \mathrm{mM} \mathrm{NaCl}$ and $0.25 \%$ Tween-20), followed by incubation in a horseradish peroxidase-conjugated secondary antibody. The immunoreactive proteins were visualized using Enhanced ChemiLuminescence (Millipore).

\section{Immunofluorescence microscopy}

Immunofluorescence analysis was performed as previously described [21]. Briefly, the OSCC cells were pretreated with various concentrations of IMD-0560 for $120 \mathrm{~min}$ and then treated with $\mathrm{TNF} \alpha(10 \mathrm{ng} / \mathrm{ml})$ for 30 min. The cells were fixed with $3.7 \%$ formaldehyde and $0.2 \%$ glutaraldehyde, blocked with $5 \%$ skim milk in PBS and incubated in an anti-human p65 polyclonal antibody $(1: 100)$ overnight at $4^{\circ} \mathrm{C}$. Then, the cells were incubated in Alexa Fluor 430-conjugated anti-rabbit IgG (1:10,000, Invitrogen, Carlsbad, CA, USA) for $90 \mathrm{~min}$ at $37^{\circ} \mathrm{C}$. The subcellular localization of Alexa Fluor 430-labeled p65 was determined via fluorescence microscopy (Biorevo, BZ-9000, Keyence, Osaka, Japan). To visualize the nuclei, the cells were stained with DAPI.

\section{Luciferase assay}

The luciferase assay was performed as previously described $[17,19,21]$. The SCCVII cells were transfected with the PBIIx-luciferase reporter using GeneJuice transfection reagent (Merck, Darmstadt, Germany) according to the manufacturer's instructions. The luciferase activity was measured using a dual luciferase reporter assay system (Promega, Madison, WI, USA).

\section{Cell invasion assay}

Cell migration was assessed in a modified Boyden chamber containing a gelatin-coated porous membrane. IMD-0560 was placed in the upper chamber $2 \mathrm{hrs}$ prior to $\mathrm{TNF} \alpha$ treatment, and $\mathrm{TNF} \alpha$ was placed in the lower chamber at $10 \mathrm{ng} / \mathrm{ml}$; then, the chamber was incubated for $24 \mathrm{hrs}$. Next, the cells attached to the upper surface of the 
membrane were scraped off, and the cells that migrated to the lower surface were fixed and stained with DAPI.

\section{Zymography}

The serum-free conditioned medium was collected from a confluent culture of OSCC cells incubated in the presence of reagents for $24 \mathrm{hrs}$. The conditioned medium was resolved via $10 \%$ SDS-PAGE in the presence of 1 $\mathrm{mg} / \mathrm{ml}$ gelatin. The resulting gel was washed in $10 \mathrm{mM}$ Tris ( $\mathrm{pH} 8.0$ ) containing 2.5\% Triton X-100, followed by incubation for $16 \mathrm{hrs}$ in a reaction buffer $(50 \mathrm{mM}$ Tris, $\mathrm{pH} 8.0,0.5 \mathrm{mM} \mathrm{CaCl}_{2}$, and $10^{-6} \mathrm{M} \mathrm{ZnCl}_{2}$ ) at $37^{\circ} \mathrm{C}$. After staining with Coomassie brilliant blue R-250, the gelatinases were identified as clear bands of lysed gelatin against a blue background.

\section{Real-time reverse transcription polymerase chain reaction (RT-PCR)}

Total RNA from the OSCC cells was prepared using TRIzol reagent (Invitrogen) and then reversetranscribed into cDNA. Real time RT-PCR was performed as previously described [31]. The primer sequences were shown in Supplementary Table 1.

\section{Animal model of bone invasion}

Sixty male $\mathrm{C} 3 \mathrm{H} / \mathrm{HeN}$ mice, which were obtained from CLEA (Tokyo, Japan) weighing approximately 20 $\mathrm{g}$ at 8 to 10 weeks of age were used to establish a model of mandible invasion by OSCC cells $[32,33]$. The animal experiments were conducted according to the guidelines for the treatment of experimental animals of Kyushu Dental University. The mice were randomly separated into six groups with similar average body weights. They were anesthetized using ether, and $0.1 \mathrm{ml}$ of SCCVII $\left(1.0 \times 10^{5 /}\right.$ $\mathrm{ml}$ ) in DMEM was injected into the left masseter region. One week (early treatment: E) or 2 weeks (late treatment: L) after injection, the mice were injected between the left masseter region and the surface of the left mandibular bone with vehicle (50 $\mu$ l of carboxymethyl-cellulose: CMC/mouse, $\mathrm{n}=10$ ) or IMD-0560 (3 or $5 \mathrm{mg} / \mathrm{kg} / 50 \mu \mathrm{l}$ of $\mathrm{CMC} /$ mouse, $\mathrm{n}=10$ ), 3 times per week for a total of 3 weeks (E) or 2 weeks (L). The tumor sizes were assessed using calipers, and the tumor volume was calculated using the following formula: width ${ }^{2} \mathrm{x}$ length $\mathrm{x} 0.52$ [34]. At the end of week 3 , all surviving mice were euthanized, and the heads of the mice were fixed in $3.7 \%$ formaldehyde (Wako Pure Chemical Industries, Ltd., Osaka, Japan).

Three-dimensional (3-D) reconstructed images of the heads were obtained via microfocal computed tomography ( $\mu-\mathrm{CT})$ (ScanXmate-E090, Comscan, Kanagawa, Japan) as previously described (21). The extent of zygoma destruction was scored using the reconstructed $\mu$-CT images as follows: 0: normal; 1: asymmetric; 2 : displaying a hairline fracture; 3: zygoma completely separated; and 4: destruction of more than $1 / 3$ of the zygoma. The images were evaluated in a blinded manner by 8 researchers [21].

Formaldehyde-fixed paraffin-embedded sections at a thickness of $5 \mu \mathrm{m}$ were generated posterior of the lower third molar and were stained with hematoxylin \& eosin (H\&E) and tartrate-resistant acid phosphatase (TRAP). Some specimens were processed for immunohistochemical staining with anti-RANKL and anti-MMP-9 antibodies (1:100) using an Imm PRESS ${ }^{\mathrm{TM}}$ Reagent kit (Vector Laboratories, Burlingame, CA, USA) and Histo Fine Simple Stain MAX-PO (R) (Nichirei, Tokyo, Japan), respectively. A non-immunoreactive immunoglobulin $\mathrm{G}$ antibody was used as a negative control for immunohistochemistry. All samples were observed under a microscope.

All incubations were performed at room temperature. For each specimen, 5 tumor fields were randomly selected, and the number of TRAP-positive multinucleated cells (TRAP ${ }^{+} \mathrm{MNCs}$ ) was counted. The data are expressed as the numbers of $\mathrm{TRAP}^{+} \mathrm{MNCs} /$ bone surface $\left(\mathrm{mm}^{2}\right) /$ section.

\section{Proliferation assay}

The $5-\mu \mathrm{m}$ sections were stained with an anti-mouse Ki-67 monoclonal antibody (1:100, ab15580, Abcam, Cambridge, UK) using the immunoperoxidase technique (Dako LSAB2 System; HRP, Dako, Glostrup, Denmark). Five tumor fields for each specimen were randomly selected, and the number of Ki-67-positive cells was counted. The data are expressed as the numbers of Ki-67positive cells $/ \mathrm{mm}^{2}$ tumor area.

\section{Data analysis}

The comparisons were performed using an unpaired Student's $t$-test. The data are expressed as the mean $\pm \mathrm{SD}$; $\mathrm{p}$ values $<0.05$ were considered to be significant. For the in vivo experiments, the comparisons were performed via factorial ANOVA. When significant $F$ values were detected, Fisher's PLSD post hoc test was performed for between-group comparison. The data are expressed as the mean $\pm \mathrm{SD}$; $\mathrm{p}$ values $<0.05$ were considered to be significant.

\section{ACKNOWLEDGMENTS}

Tada Y, Sugiyama G, Kokabu S, Nakatomi C, Osawa $\mathrm{K}$ and Jimi E performed the experiments. Aoki $\mathrm{K}$, Sugamori $\mathrm{Y}$ and Ohya $\mathrm{K}$ performed the radiological assessments. Tada Y, Nakatomi C and Matsuo K 
performed the histology preparation. Okamoto M provided the SCCVII cells. Fujikawa T and Itai A provided IMD0560. Tada Y, Kokabu S, Fukushima H and Watanabe S reviewed the intermediate draft. Jimi E designed the study, performed the literature review, prepared the initial and final versions of the paper, and submitted the document.

This work was supported by a grant-in-aid from Kyushu Dental University Internal Grants (to E.J.), the Ministry of Education, Culture, Sports, Science and Technology of Japan (to K.M.: 26462792).

\section{Conflicts of interest}

We declare no conflicts of interest.

\section{REFERENCES}

1. Cohen EE, Karrison TG, Kocherginsky M, Mueller J, Egan R, Huang CH, Brockstein BE, Agulnik MB, Mittal BB, Yunus F, Samant S, Raez LE, Mehra R, Kumar P, Ondrey F, Marchand P, Braegas B, Seiwert TY, Villaflor VM, Haraf DJ, Vokes EE. Phase III Randomized Trial of Induction Chemotherapy in Patients With N2 or N3 Locally Advanced Head and Neck Cancer. J Clin Oncol. 2014; 32(25): 2735-2743

2. Haddad RI, Shin DM. Recent advances in head and neck cancer. N Engl J Med. 2008; 359(11): 1143-1154.

3. Bernier J, Bentzen SM, Vermorken JB. Molecular therapy in head and neck oncology. Nat Rev Clin Oncol. 2009; 6(5): 266-277.

4. Bahadur S, Kumar S, Tandon DA, Rath GK, De S. Combined therapy in advanced head and neck cancers. J Laryngol Otol. 1992; 106(7):621-624.

5. Rao LP, Das SR, Mathews A, Naik BR, Chacko E, Pandey M. Mandibular invasion in oral squamous cell carcinoma: investigation by clinical examination and orthopantomogram. Int J Oral Maxillofac Surg. 2004; 33(5): 454-457.

6. Pandey M, Rao LP, Das SR. Predictors of mandibular involvement in cancers of the oromandibular region. J Oral Maxillofac Surg. 2009 ;67(5): 1069-1073.

7. Kramer S, Gelber RD, Snow JB, Marcial VA, Lowry LD, Davis LW, Chandler R. Combined radiation therapy and surgery in the management of advanced head and neck cancer: final report of study 73-03 of the Radiation Therapy Oncology Group. Head Neck Surg. 1987; 10(1): 19-30.

8. Langdon JD. Training for oral and maxillofacial surgery, academic oral surgery, and surgical dentistry in the United Kingdom. J Oral Maxillofac Surg. 2006; 64(12) :18031806.

9. Guise TA, Mundy GR. Cancer and bone. Endocr Rev. 1998; 19(1): 18-54.

10. Jimi E, Furuta H, Matsuo K, Tominaga K, Takahashi T, Nakanishi O. The cellular and molecular mechanisms of bone invasion by oral squamous cell carcinoma. Oral Dis. 2011; 17(5): 462-468.

11. Ghosh S, Hayden MS. Celebrating 25 years of NF- $\kappa B$ research. Immunol Rev. 2012; 246(3): 5-13.

12. DiDonato JA, Mercurio F, Karin M. NF- $\mathrm{BB}$ and the link between inflammation and cancer. Immunol Rev. 2012; 246(1): 379-400.

13. Tanaka T, Nakayama H, Yoshitake $Y$, Irie A, Nagata M, Kawahara K, Takamune Y, Yoshida R, Nakagawa Y, Ogi H, Shinriki S, Ota K, Hiraki A, Ikebe T, Nishimura Y, Shinohara M. Selective inhibition of nuclear factor- $\kappa \mathrm{B}$ by nuclear factor- $\kappa \mathrm{B}$ essential modulator-binding domain peptide suppresses the metastasis of highly metastatic oral squamous cell carcinoma. Cancer Sci. 2012; 103(3): 455463.

14. Aggarwal BB, Sung B. NF- $\kappa B$ in cancer: a matter of life and death. Cancer Discov. 2011; 1(6): 469-471.

15. Nakayama H, Ikebe T, Beppu M, Shirasuna K. High expression levels of nuclear factor $\kappa \mathrm{B}$, I $\kappa \mathrm{B}$ kinase $\alpha$ and Akt kinase in squamous cell carcinoma of the oral cavity. Cancer. 2001; 92(12): 3037-3044.

16. Boyce BF. Advances in the regulation of osteoclasts and osteoclast functions. J Dent Res. 2013; 92(10): 860-867.

17. Jimi E, Aoki K, Saito H, D’Acquisto F, May MJ, Nakamura I, Sudo T, Kojima T, Okamoto F, Fukushima H, Okabe K, Ohya K, Ghosh S. Selective inhibition of NF- $\kappa B$ blocks osteoclastogenesis and prevents inflammatory bone destruction in vivo. Nat Med. 2004; 10(6): 617-624.

18. Dai S, Hirayama T, Abbas S, Abu-Amer Y. The IкB kinase (IKK) inhibitor, NEMO-binding domain peptide, blocks osteoclastogenesis and bone erosion in inflammatory arthritis. J Biol Chem. 2004; 279(36): 37219-37222.

19. Suzuki J, Ogawa M, Muto S, Itai A, Isobe M, Hirata Y, Nagai R. Novel IкB kinase inhibitors for treatment of nuclear factor-кB-related diseases. Expert Opin Investig Drugs. 2011;20(3):395-405.

20. Young ER IKK $\beta$ as a therapeutic intervention point diseases related to inflammation. In:Levin JI., Laufer S, eds. Antiinflammatory drug discovery. RSC Publishing. 2012; 255296.

21. Furuta H, Osawa K, Shin M, Ishikawa A, Matsuo K, Khan M, Aoki K, Ohya K, Okamoto M, Tominaga K, Takahashi T, Nakanishi O, Jimi E. Selective inhibition of NF- $\kappa B$ suppresses bone invasion by oral squamous cell carcinoma in vivo. Int J Cancer. 2012; 131(5): E625-635.

22. Okazaki Y, Sawada T, Nagatani K, Komagata Y, Inoue T, Muto S, Itai A, Yamamoto K. Effect of nuclear factor-kappaB inhibition on rheumatoid fibroblast-like synoviocytes and collagen induced arthritis. J Rheumatol. 2005; 32(8): 1440-1447.

23. Wakatsuki S, Suzuki J, Ogawa M, Masumura M, Muto S, Shimizu T, Takayama K, Itai A, Isobe M. A novel IKK inhibitor suppresses heart failure and chronic remodeling after myocardial ischemia via MMP alteration. Expert Opin 
Ther Targets. 2008; 12(12): 1469-76.

24. Orita S, Miyagi M, Kobori S, Gemba T, Ishikawa T, Inoue G, Toyone T, Aoki Y, Eguchi Y, Takahashi K, Ohtori S. I $\mathrm{B}$ kinase $\beta$ inhibitor downregulates pain-related neuropeptide production in the sensory neurons innervating injured lumbar intervertebral discs in the dorsal root ganglia of rats. Spine J. 2013; 13(3): 284-288.

25. Duffey DC, Chen Z, Dong G, Ondrey FG, Wolf JS, Brown K, Siebenlist U, Van Waes C. Expression of a dominantnegative mutant inhibitor- $\kappa \mathrm{B} \alpha$ of nuclear factor- $\kappa \mathrm{B}$ in human head and neck squamous cell carcinoma inhibits survival, proinflammatory cytokine expression, and tumor growth in vivo. Cancer Res. 1999; 59(14): 3468-3474.

26. Romieu-Mourez R, Landesman-Bollag E, Seldin DC, Traish AM, Mercurio F, Sonenshein GE. Roles of IKK kinases and protein kinase $\mathrm{CK} 2$ in activation of nuclear factor $-\mathrm{\kappa B}$ in breast cancer. Cancer Res 2001; 61(9): 3810-3818.

27. Sodek KL, Murphy KJ, Brown TJ, Ringuette MJ. Cellcell and cell-matrix dynamics in intraperitoneal cancer metastasis. Cancer Metastasis Rev. 2012; 31(1-2): 397-414.

28. Bond M, Fabunmi RP, Baker AH, Newby AC. Synergistic upregulation of metalloproteinase-9 by growth factors and inflammatory cytokines: an absolute requirement for transcription factor NF-kB. FEBS Lett. 1998; 435(1): 2934.

29. Ikebe T, Takeuchi H, Jimi E, Beppu M, Shinohara M, Shirasuna KInvolvement of proteasomes in migration and matrix metalloproteinase-9 production of oral squamous cell carcinoma. Int J Cancer. 1998; 77(4): 578-585.

30. Shindoh M, Higashino F, Kaya M, Yasuda M, Funaoka $\mathrm{K}$, Hanzawa M, Hida K, Kohgo T, Amemiya A, Yoshida K, Fujinaga K. Correlated expression of matrix metalloproteinases and ets family transcription factor E1A-F in invasive oral squamous-cell-carcinoma-derived cell lines. Am J Pathol. 1996; 148(3): 693-700.

31. Nakamura H, Aoki K, Masuda W, Alles N, Nagano K, Fukushima H, Osawa K, Yasuda H, Nakamura I, MikuniTakagaki Y, Ohya K, Maki K, Jimi E. Disruption of NF$\kappa \mathrm{B} 1$ prevents bone loss caused by mechanical unloading. J Bone Miner Res. 2013; 28(6): 1457-1467.

32. Nomura T, Shibahara T, Katakura A, Matsubara S, Takano $\mathrm{N}$. Establishment of a murine model of bone invasion by oral squamous cell carcinoma. Oral Oncol. 2007; 43(3): 257-262.

33. Cui N, Nomura T, Noma H, Yokoo K, Takagi R, Hashimoto S, Okamoto M, Sato M, Yu G, Guo C, Shibahala T. Effect of YM529 on a model of mandibular invasion by oral squamous cell carcinoma in mice. Clin Cancer Res. 2005; 11(7): 2713-2719.

34. Shin M, Kadowaki T, Iwata J, Kawakubo T, Yamaguchi N, Takii, Tsukuba T, Yamamoto K. Association of cathepsin E with tumor growth arrest through angiogenesis inhibition and enhanced immune responses. Biol Chem. 2007; 388(11): 1173-1181. 